\title{
Critical progesterone requirement for maintenance of pregnancy in ovariectomized rats
}

\author{
W. Arkaravichien and K. E. Kendle \\ School of Pharmacy, Robert Gordon's Institute of Technology, Aberdeen AB9 IFR, UK
}

\begin{abstract}
Summary. The minimum progesterone concentration required to maintain the pregnancy was studied by varying doses of progesterone given subcutaneously to rats ovariectomized on Day 8 of pregnancy. Injecting $3 \mathrm{mg}$ progesterone plus $200 \mathrm{ng}$ oestradiol benzoate daily provided serum progesterone values betwen $25.4 \pm 7.0$ and $35 \cdot 2 \pm 6 \cdot 2 \mathrm{ng} / \mathrm{ml}$ throughout Days 10-19 which were significantly lower than normal levels $(P<0.05)$, but resulted in $93.6 \%$ of fetal survival on Day 19 which was not significantly different from $93.3 \%$ in the control group. Injecting $2 \mathrm{mg}$ progesterone plus $200 \mathrm{ng}$ oestradiol benzoate daily gave progesterone values between $13.2 \pm 4.6$ and $19.0 \pm 6.2 \mathrm{ng} / \mathrm{ml}$ and could not maintain fetal viability to Day $19(14.2 \%, P<0.05$ compared with control group).

Critical times to supplement progesterone in rats ovariectomized on Day 8 or Day 15 were studied by varying the time of progesterone implantation after ovariectomy. Progesterone implants were administered 8, 12 and $24 \mathrm{~h}$ after ovariectomy on Day 8 and 24,36 and $48 \mathrm{~h}$ after ovariectomy on Day 15. On Day 8, progesterone replacement could be delayed to $8 \mathrm{~h}$ but not $12 \mathrm{~h}$, while on Day 15 , progesterone replacement could be delayed up to $36 \mathrm{~h}$ but not $48 \mathrm{~h}$ after ovariectomy without affecting fetal survival.
\end{abstract}

Keywords: progesterone; rat pregnancy; abortion; ovariectomy

\section{Introduction}

Progesterone is essential to initiate embryo implantation and to maintain pregnancy in eutherian mammals (Rothchild, 1983). The depletion of sex hormones in pregnant rats induced by ovariectomy results in pregnancy termination (Deanesly, 1973). However, pregnancy termination in ovariectomized rats can be prevented by giving hormone supplements (Pepe \& Rothchild, 1973; MacDonald, 1982). Progesterone used in the ovariectomized rats to maintain the pregnancy in various studies ranged from 3 to $20 \mathrm{mg}$ /day. Lerner et al. (1962) suggested that the optimum subcutaneous dose to maintain the pregnancy in rats ovariectomized on Day 8 of pregnancy was $20 \mathrm{mg} /$ day. Tamada \& Ichikawa (1980) injected only $4 \mathrm{mg}$ progesterone/day plus $200 \mathrm{ng}$ oestradiol/ day to rescue the fetuses of Day-14 pregnant ovariectomized rats. MacDonald (1982) injected $3 \mathrm{mg}$ progesterone/day plus oestradiol to rats ovariectomized on Day 3 in order to maintain the free blastocyst and support the implantation and pregnancy through to Day 20. Unfortunately, in those studies, serum progesterone concentrations were not determined. Some investigators have suggested that the progesterone concentrations that are required in pregnant rats need not be as high as are actual physiological values (Pepe \& Rothchild, 1973; Legrand et al., 1979). Pepe \& Rothchild (1973) showed that serum progesterone concentrations between 30 and $80 \mathrm{ng} / \mathrm{ml}$ could maintain the pregnancy to Day 22 in rats ovariectomized on Day 6, but they did not show whether pregnancy could be maintained by lower serum progesterone levels. The critical progesterone requirement for pregnancy maintenance, therefore, has not been fully determined. The purposes of this study were to determine the minimum serum progesterone concentration needed to maintain 
the pregnancy under conditions of adequate oestrogen replacement, and also to investigate the critical time of progesterone supplement after ovariectomy for the rescue of the fetuses in rats.

Previous studies have documented the changes in physiological progesterone concentrations in pregnant rats. These changes can be divided into a pre-implantation rise of the values from Days 1 to 4 , a plateau phase from Days 5 to 10 then a rise and fall with the maximum levels during Days 15-19 (Morishige et al., 1973; Bridges, 1984). In the present study, Day 8 was selected for investigation as typical of the post-implantation plateau phase and Day 15 as the time of the physiological peak levels. These times were of particular interest in view of the current clinical use of antiprogestagens as abortifacients and represent suitable times for detailed further study of the mechanisms involved. This information will be of value in determining the optimal pharmacokinetic properties of antiprogestagens.

\section{Materials and Methods}

Female Sprague-Dawley rats aged 9-13 weeks were housed as described previously (Kendle, 1975). Vaginal smears were taken every morning after pairing with male rats overnight. The day of a positive sperm smear was defined as Day 1 of pregnancy.

Progesterone, oestradiol and sesame oil used in this study were purchased from Sigma, St Louis, MO, USA.

\section{Minimum progesterone required to maintain pregnancy}

Day-8 pregnant rats were randomly allocated to ovariectomy or sham ovariectomy under light ether anaesthesia. Sham-ovariectomized rats received $0.2 \mathrm{ml}$ sesame oil by subcutaneous injection while ovariectomized rats received $3 \mathrm{mg}$ or $2 \mathrm{mg}$ progesterone plus $200 \mathrm{ng}$ oestradiol benzoate injection daily from Day 8 to Day 18 . Blood samples were taken for progesterone assay by cardiac puncture under light ether anaesthesia on Days 10,13,16 and 19 just before the time of injections. All rats were killed on Day 19 when fetuses were quickly removed from the uterus to examine for survival as indicated by the presence of heart beat. The number of surviving fetuses and number of implantation sites were counted, and proportion of fetal survival was calculated in each treatment group. Fetal growth was determined by measuring length and by weighing the live fetuses. Placental weight was also separately recorded.

\section{Critical time for progesterone replacement}

The critical time to supplement progesterone after ovariectomy was studied by varying the time of progesterone replacement to rats ovariectomized on Day 8 or Day 15 of pregnancy. Progesterone was administered by dorsal subcutaneous implants which were prepared by mixing progesterone with curing agent and then mixing with medical grade Silastic elastomer (Dow Corning, Midland, MI, USA) in a proportion of curing agent to elastomer of 1:10 to make $10 \%(\mathrm{w} / \mathrm{w})$ progesterone. The mixture was left to cure and was cut to $5 \times 40 \mathrm{~mm}$ size pieces which weighed $308.5 \pm 6.5 \mathrm{mg}$. The implants were tested to ensure that they provided serum progesterone concentrations above the minimum required level throughout the period of study: 8 rats were ovariectomized on Day 8 , given implants and blood sampled on Days 9, 11, 13 and 15. Similarly, 6 Day-15 pregnant rats were ovariectomized, implanted with progesterone, then blood sampled on Days 16, 17, 18, 19 and 20.

Day 8 ovariectomy. The serum progesterone profile after ovariectomy was studied by taking blood samples from 8 Day-8 pregnant rats immediately before ovariectomy and then again at 4,8,12,24, 48, 72, 96, 120 and $144 \mathrm{~h}$ after operation.

Nine rats were sham-operated and received daily injections of sesame oil. Further groups of 10, 10,9 and 5 rats were ovariectomized on Day 8 and received daily injections of $200 \mathrm{ng}$ oestradiol benzoate and progesterone implants immediately or at 8,12 or $24 \mathrm{~h}$ after ovariectomy. All rats were killed on Day 15 and proportions of fetal survival were calculated.

Day 15 ovariectomy. Similarly, 7 Day-15 pregnant rats were ovariectomized and blood samples were taken immediately before, then at $2,4,8,12,24,48,72,96,120$ and $144 \mathrm{~h}$ after operation for the study of progesterone profile after ovariectomy.

Five rats were sham operated and received placebo implants, then were killed on Day 18. Groups of 5, 9, 5,11 and 11 rats were ovariectomized on Day 15 and received placebo implants or progesterone implants immediately after ovariectomy, or 24,36 , or $48 \mathrm{~h}$ later. The animals were killed on Day 18 and examined for survival of fetuses.

The effect of oestrogen on the critical time of progesterone replacement was studied by injecting $200 \mathrm{ng}$ oestradiol benzoate/day to 7 rats ovariectomized on Day 15 and receiving progesterone implants after a 48-h delay. 


\section{Serum progesterone assay}

All blood samples were centrifuged after clotting to separate serum which was kept at $-20^{\circ} \mathrm{C}$ until assay which was done within 1 month. The assay was done by RIA using a commercial Gamma B Progesterone Kit (IDS, Washington, UK) with a sensitivity of $0.5 \mathrm{nmol} / \mathrm{l}$. The intra-assay and interassay coefficients of variation were $9.6 \%$ and $12 \%$ respectively.

\section{Statistics}

Significance of difference in the proportions of fetal survival in each treatment group was determined by the $\chi^{2}$ test. Fetal length, fetal weight and placental weight were recorded from every live fetus, then expressed as mean \pm s.d. for each treatment group. One-way analysis of variance, followed when appropriate by the Kramer modification of Duncan's multiple range test, was used to establish significance of difference of the means (Milton \& Tsokos, 1983).

\section{Results}

\section{Minimum progesterone required to maintain pregnancy}

Table 1 shows serum progesterone concentrations of sham-ovariectomized rats and of ovariectomized rats treated with 3 or $2 \mathrm{mg}$ progesterone/day plus $200 \mathrm{ng}$ oestradiol benzoate/day. Serum progesterone values in rats treated with $3 \mathrm{mg}$ progesterone/day were significantly lower than in sham-operated rats, and the concentrations in rats given $2 \mathrm{mg}$ /day were significantly lower than in those given $3 \mathrm{mg}$ progesterone/day $(P<0.05)$.

Table 1. Mean ( \pm s.d.) serum progesterone concentrations ( $\mathrm{ng} / \mathrm{ml}$ ) in sham-operated rats and rats ovariectomized on Day 8 of gestation and treated with 3 or $2 \mathrm{mg}$ progesterone $+200 \mathrm{ng}$ oestradiol benzoate/day

\begin{tabular}{lcccc}
\hline Day & $\begin{array}{c}\text { Sham ovariectomy } \\
\text { vehicle } \\
(\mathrm{N}=5)\end{array}$ & $\begin{array}{c}\text { Ovariectomy }+3 \mathrm{mg} \\
\text { progesterone } \\
(\mathrm{N}=9)\end{array}$ & $\begin{array}{c}\text { Ovariectomy }+2 \mathrm{mg} \\
\text { progesterone } \\
(\mathrm{N}=8)\end{array}$ & ANOVA \\
\hline Day 10 & $43.1 \pm 4.3$ & $25.4 \pm 7.0$ & $13.2 \pm 4.6$ & $P<0.05^{*}$ \\
Day 13 & $55.4 \pm 11.0$ & $35.2 \pm 6.2$ & $19.0 \pm 6.2$ & $P<0.05^{*}$ \\
Day 16 & $70.4 \pm 16.3$ & $27.0 \pm 8.9$ & $14.1 \pm 2.6$ & $P<0.05^{*}$ \\
Day 19 & $60.8 \pm 12.8$ & $26.8 \pm 5.6$ & $17.7 \pm 3.5$ & $P<0.05^{*}$ \\
\hline
\end{tabular}

*Each value is significantly different from each of the others in the same day (one-way analysis of variance).

The proportion of fetal survival on Day 19 in rats ovariectomized on Day 8 and given $3 \mathrm{mg}$ progesterone plus $200 \mathrm{ng}$ oestradiol benzoate daily was not significantly different from the value of sham-operated rats. Those given $2 \mathrm{mg}$ progesterone/day plus $200 \mathrm{ng}$ oestradiol benzoate/day had significantly reduced fetal survival on Day 19 (Table 2). Fetal length in progesterone-treated animals was not significantly different from the value in sham-operated rats. Fetal weight in rats receiving $3 \mathrm{mg}$ progesterone/day was not significantly different from that in sham-operated rats, but rats receiving $2 \mathrm{mg}$ progesterone/day had significantly lower fetal weight. Placental weights in both treatment groups were higher than in the sham-operated group (Table 2).

\section{Critical time for progesterone replacement}

Day 8 ovariectomy. As shown in Fig. 1(a) serum progesterone concentrations in ovariectomized rats without progesterone replacement dropped from $57.4 \pm 14.4 \mathrm{ng} / \mathrm{ml}$ before ovariectomy to $10.6 \pm 2.6 \mathrm{ng} / \mathrm{ml}$ at $4 \mathrm{~h}$ after operation, and then slightly increased to $14.9 \pm 3.1 \mathrm{ng} / \mathrm{ml}$ at $8 \mathrm{~h}$ after ovariectomy. Values declined again with an elimination rate constant of $0.02 \mathrm{~h}^{-1}$ to a level of around $6 \mathrm{ng} / \mathrm{ml}$ at $48 \mathrm{~h}$ and remained around this concentration throughout the period of study. 
Table 2. Fetal survival, fetal growth and placental weight in rats sham ovariectomized on Day 8 of pregnancy and given vehicle and rats ovariectomized on Day 8 treated with 3 or $2 \mathrm{mg}$ progesterone $+200 \mathrm{ng}$ oestradiol benzoate/day

\begin{tabular}{|c|c|c|c|c|}
\hline \multirow[b]{2}{*}{ Groups } & \multirow[b]{2}{*}{$\begin{array}{c}\text { Fetal survival } \\
\text { on Day } 19\end{array}$} & \multicolumn{2}{|c|}{ Fetal growth } & \multirow{2}{*}{$\begin{array}{l}\text { Placental } \\
\text { weight } \\
\text { (g) }\end{array}$} \\
\hline & & $\begin{array}{l}\text { Length } \\
(\mathrm{mm})\end{array}$ & $\begin{array}{l}\text { Weight } \\
\text { (g) }\end{array}$ & \\
\hline $\begin{array}{l}\text { Sham- } \\
\text { ovariectomy }\end{array}$ & $\begin{array}{c}102 / 109(93.6 \%) \\
(\mathrm{N}=7)\end{array}$ & $\begin{array}{l}26 \cdot 4 \pm 1 \cdot 2 \\
(\mathrm{~N}=78)\end{array}$ & $\begin{array}{l}1.4 \pm 0.2 \\
(\mathrm{~N}=78)\end{array}$ & $\begin{aligned} 0.47 & \pm 0.06 \\
(\mathrm{~N} & =78)\end{aligned}$ \\
\hline $\begin{array}{l}\text { Ovariectomy }+3 \mathrm{mg} \\
\text { progesterone }\end{array}$ & $\begin{array}{c}78 / 83 \quad(93.9 \%) \\
(\mathrm{N}=9)\end{array}$ & $\begin{array}{l}26 \cdot 2 \pm 1 \cdot 2 \\
(\mathrm{~N}=102)\end{array}$ & $\begin{array}{l}1 \cdot 4 \pm 0 \cdot 2 \\
(\mathrm{~N}=102)\end{array}$ & $\begin{aligned} 0.56 & \pm 0.08^{*} \\
(\mathrm{~N} & =102)\end{aligned}$ \\
\hline $\begin{array}{l}\text { Ovariectomy }+2 \mathrm{mg} \\
\text { progesterone }\end{array}$ & $\begin{array}{c}32 / 226(14 \cdot 2 \%)^{* *} \\
(\mathrm{~N}=19)\end{array}$ & $\begin{array}{l}25 \cdot 8 \pm 1 \cdot 8 \\
(\mathrm{~N}=32)\end{array}$ & $\begin{array}{l}1 \cdot 3 \pm 0 \cdot 2^{*} \\
(\mathrm{~N}=32)\end{array}$ & $\begin{aligned} 0.53 & \pm 0.09 * \\
(\mathrm{~N} & =32)\end{aligned}$ \\
\hline
\end{tabular}

Values are means \pm s.d.

*Significantly different from sham-ovariectomized rats, $P<0.05$ (ANOVA).

**Significantly different from values of the other 2 groups, $P<0.01\left(\chi^{2}\right)$.

Serum progesterone concentrations in ovariectomized rats implanted with progesterone declined from $52.5 \pm 5.5 \mathrm{ng} / \mathrm{ml}$ on Day 9 to $25.9 \pm 5.9 \mathrm{ng} / \mathrm{ml}$ on Day 15 , but the values were above the minimum required level for maintenance of pregnancy throughout (Fig. 1a).

The proportion of fetal survival on Day 15 in rats ovariectomized on Day 8 and receiving progesterone implants immediately or after $8 \mathrm{~h}$ was not significantly different from the figure in the sham-operated rats, but when progesterone replacement was delayed up to $12 \mathrm{~h}$ after ovariectomy, fetal survival on Day 15 was just $17 \cdot 1 \%$, significantly different from that in the sham-operated group. Delay of progesterone replacement to $24 \mathrm{~h}$ after ovariectomy reduced fetal survival to zero (Table 3).

Day 15 ovariectomy. Serum progesterone concentrations dropped from $63 \cdot 8 \pm 13 \cdot 1 \mathrm{ng} / \mathrm{ml}$ before ovariectomy on Day 15 to $19 \cdot 2 \pm 3.0 \mathrm{ng} / \mathrm{ml}$ at $8 \mathrm{~h}$ after operation and then slightly increased to $23.8 \pm 5.5 \mathrm{ng} / \mathrm{ml}$ at $12 \mathrm{~h}$ (Fig. 1b). Again, the level declined with an elimination rate constant of $0.02 \mathrm{~h}^{-1}$ to values around $6 \mathrm{ng} / \mathrm{ml}$ at $96 \mathrm{~h}$, then remained around this level throughout the study period.

Progesterone implants in rats ovariectomized on Day 15 provided serum progesterone concentrations above the minimum required level throughout the period. The levels declined from $58.9 \pm 9 \cdot 7 \mathrm{ng} / \mathrm{ml}$ on Day 16 to $46 \cdot 4 \pm 9 \cdot 6 \mathrm{ng} / \mathrm{ml}$ on Day 18 (Fig. $1 \mathrm{~b}$ ).

In rats ovariectomized on Day 15 of pregnancy, progesterone alone could rescue fetuses up to Day 18 , while placebo could not. Delay in progesterone replacement of 24 or $36 \mathrm{~h}$ after ovariectomy did not make any difference to the survival of fetuses compared to sham-ovariectomized rats. However, delay in progesterone replacement up to $48 \mathrm{~h}$ after ovariectomy resulted in a significantly lower proportion of fetal survival than that in sham-operated rats (Table 4).

When $200 \mathrm{ng}$ oestradiol benzoate/day were injected together with progesterone implants, a delay of $48 \mathrm{~h}$ resulted in a proportion of fetal survival on Day 18 not significantly different from that in ovariectomized rats receiving progesterone alone after a 48-h delay (Table 4).

\section{Discussion}

To maintain the pregnancy in rats ovariectomized on Day 8, Lerner et al. (1962) had to inject progesterone in doses as high as $20 \mathrm{mg} /$ day because oestrogen was not also given, but if oestrogen was co-injected, the progesterone requirement was lower. In our study, an adequate dose of oestrogen was injected and different doses of progesterone were administered to determine the minimum progesterone concentrations required. It was found that $3 \mathrm{mg}$ progesterone/day, given sub- 


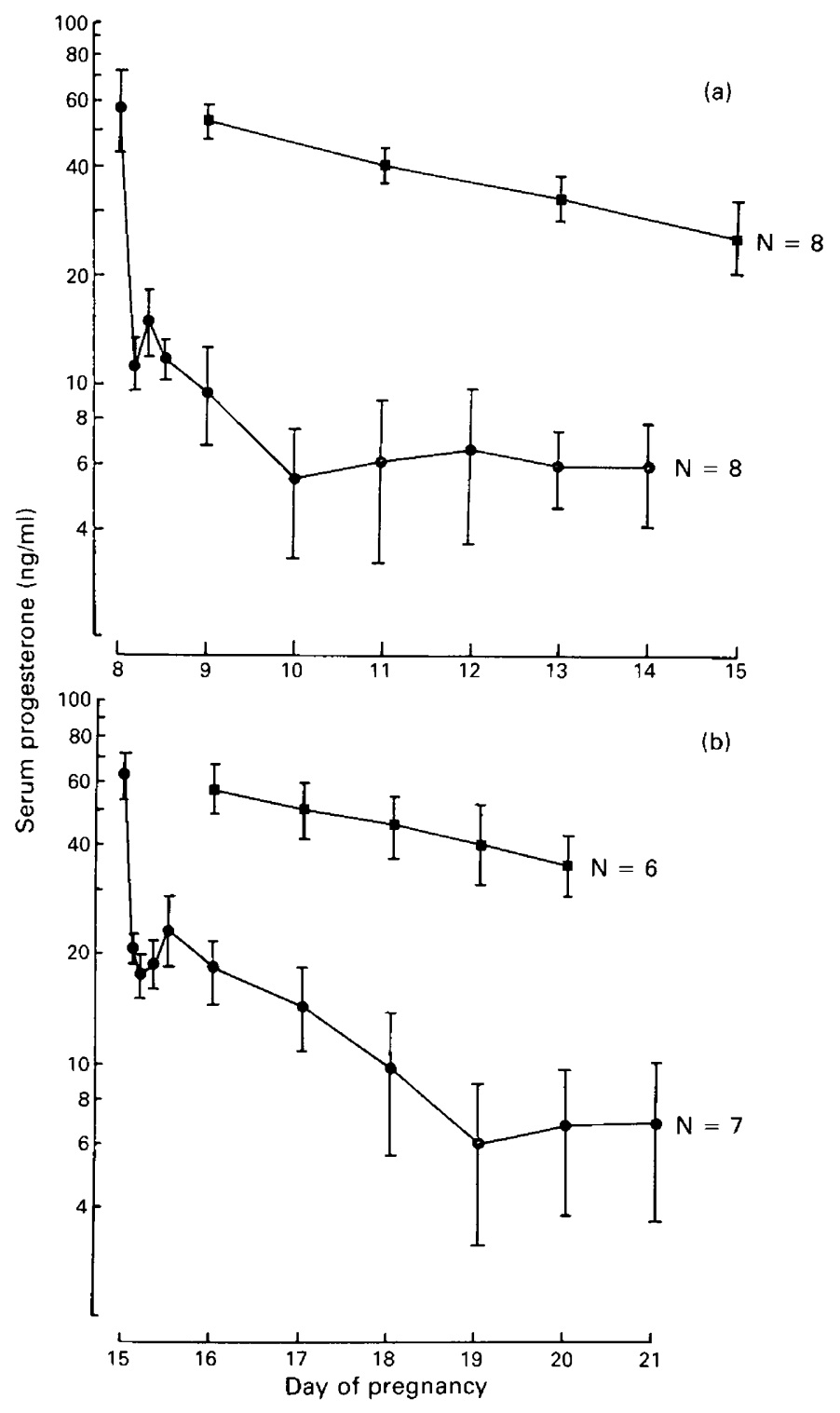

Fig. 1. Serum progesterone concentrations in (a) rats ovariectomized on Day 8 and with ( $\boldsymbol{\square}$ ) or without (O) progesterone implants and (b) rats ovariectomized on Day 15 and with ( $\boldsymbol{E}$ ) or without (O) progesterone implants.

cutaneously, gave progesterone concentrations around $30 \mathrm{ng} / \mathrm{ml}$, which was enough, whereas $2 \mathrm{mg}$ progesterone/day, which provided serum progesterone values of less than $20 \mathrm{ng} / \mathrm{ml}$, was not enough to maintain full fetal viability. The need for oestrogen in addition to progesterone to maintain pregnancy has also been shown by Pepe \& Rothchild (1973), Tamada \& Ichikawa (1980) and MacDonald (1982). Especially in late pregnancy, oestrogen is necessary to ensure sufficient plasticity of the uterine tissue (Tamada \& Ichikawa, 1980).

Progesterone concentrations in rats injected with $3 \mathrm{mg}$ progesterone/day were significantly lower than in the control group, but the proportions of fetal survival on Day 19 in both groups were not significantly different. Serum progesterone values in pregnant rats can therefore be lower 
Table 3. Fetal survival on Day 15 in rats sham ovariectomized (OVX) on Day 8 of pregnancy and in rats ovariectomized on Day 8 and given $200 \mathrm{ng}$ oestradiol benzoate/day + progesterone implants at various times after ovariectomy

\begin{tabular}{lcc}
\hline Treatment groups & No. of rats & Fetal survival \\
\hline Sham OVX + placebo & 9 & $66 / 73(90 \cdot 4 \%)$ \\
OVX + progesterone immediately & 10 & $128 / 140(91 \cdot 4 \%)$ \\
OVX + delay progesterone $8 \mathrm{~h}$ & 10 & $129 / 145(88.9 \%)$ \\
OVX + delay progesterone $12 \mathrm{~h}$ & 9 & $28 / 164(17 \cdot 1 \%)^{* *}$ \\
OVX + delay progesterone $24 \mathrm{~h}$ & 5 & 0 \\
\hline
\end{tabular}

**Significantly different $\left(P<0.01, \chi^{2}\right)$ from each of the first three groups which are not significantly different from each other.

Table 4. Fetal survival on Day 18 in rats sham ovariectomized (OVX) or ovariectomized on Day 15 of pregnancy and given progesterone implants at various times after ovariectomy and in rats given $200 \mathrm{ng}$ oestradiol benzoate/day in addition to a $48 \mathrm{~h}$ progesterone delay

\begin{tabular}{lcc}
\hline Treatment groups & No. of rats & Fetal survival \\
\hline Sham OVX + placebo & 5 & $67 / 67(100 \%)$ \\
OVX + progesterone immediately & 9 & $175 / 184(95 \cdot 1 \%)$ \\
OVX + delay progesterone $24 \mathrm{~h}$ & 5 & $73 / 76(96 \cdot 1 \%)$ \\
OVX + delay progesterone $36 \mathrm{~h}$ & 11 & $135 / 150(90 \cdot 0 \%)$ \\
OVX + delay progesterone $48 \mathrm{~h}$ & 11 & $77 / 148(52 \cdot 0 \%)^{* *}$ \\
OVX + oest. + delay progesterone $48 \mathrm{~h}$ & 7 & $39 / 74(52 \cdot 7 \%)^{* *}$ \\
OVX + placebo & 5 & $7 / 76 \quad(9 \cdot 2 \%)^{* *}$ \\
\hline
\end{tabular}

${ }^{* *}$ Significantly different $\left(P<0.01, \chi^{2}\right)$ from each of the first four groups which are not significantly different from each other.

than the actual physiological level without affecting survival or the growth of fetuses. Labhsetwar $\&$ Watson (1974) have shown the rise of oestradiol and the fall of progesterone serum concentrations, resulting in an increasing oestrogen:progesterone ratio at term, which is believed to initiate the parturition. Inoue (1981) has also shown that parturition could not occur, even at term, if the oestrogen:progesterone ratio was not correct. It is therefore possible that pregnant rats may sustain higher progesterone concentrations than is required for maintenance of pregnancy in order to prepare for the change of oestrogen:progesterone ratio which is essential for parturition when the pregnancy comes to term.

In our experiment, uterine progesterone was not assayed because, in rats, the placenta is not a site of progesterone production. Legrand et al. (1979) had already shown that uterine progesterone concentrations were proportional to plasma progesterone concentrations, and it originated from peripheral blood and not from the placenta.

Reduction of the progesterone concentration to about $50 \%$ did not affect the normal growth of fetuses, at least from Days 8 to 19 , as shown by fetal length and fetal weight in ovariectomized rats treated with $3 \mathrm{mg}$ progesterone/day. However, if the level fell too far, as in rats treated with $2 \mathrm{mg}$ progesterone/day, fetal weight was significantly lower although no difference in fetal length was seen. This implies that fetal weight is a more sensitive index of growth than fetal length. Uterine blood supply may be altered by progesterone deprivation, and this may explain altered growth. This possibility is being currently investigated. Placental weights in ovariectomized rats treated with 2 or 
$3 \mathrm{mg}$ progesterone/day were significantly higher than placental weight in sham-ovariectomized rats. Csapo \& Wiest (1969) also demonstrated hypertrophy of the placenta in ovariectomized rats. Wilson \& Lindsey (1987) have shown that progesterone withdrawal is a potent stimulus for uterine prostaglandin synthesis. Prostaglandins are the known cause of tissue inflammation and a cause of increasing capillary permeability (Moncada et al., 1980). Therefore, this placental hypertrophy may be a result of fluid infiltration caused by an increasing level of prostaglandins when progesterone concentration drops.

Serum progesterone profiles in rats ovariectomized on Day 8 or Day 15 of pregnancy showed a dramatic fall after the operation, but the concentrations increased slightly at $8 \mathrm{~h}$ and $12 \mathrm{~h}$ after ovariectomy on Day 8 and Day 15 respectively. These slight rises of about $6 \mathrm{ng} / \mathrm{ml}$ could be explained by a compensatory mechanism of progesterone production by the adrenal gland. While the effects of combined ovariectomy and adrenalectomy was not investigated in the present study, Lu \& Judo (1982) found a similar rise of progesterone level after ovariectomy in cyclic rats which was abolished by simultaneous adrenalectomy. Accordingly, after chronic ovariectomy, progesterone concentrations were around $6 \mathrm{ng} / \mathrm{ml}$ (Fig. 1a, b). In addition, ovariectomy in early and late pregnancy resulted in the same progesterone elimination rate constant of $0.02 \mathrm{~h}^{-1}$.

The study of critical time for progesterone replacement after ovariectomy was determined by administering progesterone implants at various times to ovariectomized rats in early or midpregnancy. Rats ovariectomized on Day 8 were given progesterone plus oestradiol while rats ovariectomized on Day 15 were treated with progesterone along because the results in Table 4 show that progesterone alone could maintain the pregnancy up to Day 18. Progesterone implants were used in this study to prevent fluctuation of serum concentrations. Our unpublished data confirm that the implants released progesterone above the required levels within $2 \mathrm{~h}$. Progesterone replacement could be delayed until serum progesterone concentrations dropped to about $15 \mathrm{ng} / \mathrm{ml}$, but the minimum required level had to be above $20 \mathrm{ng} / \mathrm{ml}$ (Tables $1 \& 2$ ) otherwise fetal survival was significantly reduced. This means that serum progesterone can fall below the minimum required level for a period provided that it is restored to over $20 \mathrm{ng} / \mathrm{ml}$ within a critical period which depends upon the stage of the pregnancy. Injecting $200 \mathrm{ng}$ oestradiol benzoate/day did not help to prolong this critical time of progesterone replacement, since fetal survival was not significantly different from that in ovariectomized rats receiving progesterone alone.

\section{References}

Bridges, R.B. (1984) A quantitative analysis of the roles of dosage, sequence, and duration of oestradiol and progesterone exposure in the regulation of maternal behavior in the rat. Endocrinology 114, 930-940.

Csapo, A. \& Wiest, W. (1969) An examination of the quantitative relationship between progesterone and the maintenance of pregnancy. Endocrinology 85, $735-746$.

Deanesly, R. (1973) Termination of early pregnancy in rats after ovariectomy is due to immediate collapse of progesterone dependent decidua. J. Reprod. Fert. 35, 183-186.

Inoue, S. (1981) Experimental simulation of neuroendocrine dynamics at parturition periods: a synthetic approach to pregnancy maintenance, parturition and lactation by programmed infusion of sex steroids in ovariectomized rats. Endocrinol. Japan. 28, 747-755.

Kendle, K.E. (1975) Some biological properties of RMI 12936 , a new synthetic antiprogestational steroid. $J$. Reprod. Fert. 43, 505-513.

Labhsetwar, A.P. \& Watson, D.J. (1974) Temporal relation between secretory patterns of gonado- tropins, estrogens, progestins, and prostaglandin $F$ in periparturient rats. Biol. Reprod. 10, 103-110.

Legrand, C., Synguelakis, M., Emmerich, A. \& Robel, P. (1979) Relationships among placental, uterine, and circulating concentrations of progesterone and fetal survival in the ovariectomized pregnant rat. Endocrinology 105, 58-63.

Lerner, L., Brennan., Yiacas, E., DePhillipo, M. \& Borman, A. (1962) Pregnancy maintenance in ovariectomized rats with $16 \alpha, 17 \alpha$ dihydoxy-progesterone derivatives and other progestogens. Endocrinology 70, 283-287.

Lu, J.K.H. \& Judo, H.L. (1982) Silastic implant of progesterone produced high circulating levels of both progesterone and $20 \alpha$ hydroxyprogesterone in ovariectomized rats. Biol. Reprod. 26, 385-390.

MacDonald, G.J. (1982) Maintenance of pregnancy in ovariectomized rats with steroid analogs and the reproductive ability of the progeny. Biol. Reprod. 27, 261-267.

Milton, J.S. \& Tsokos, J.O. (1983) Statistical Methods in the Biological and Health Sciences. McGraw-Hill, Inc. 
Moncada, S., Flower, R.J. \& Vane, J.R. (1980) Prostaglandins, prostacyclin, and thromboxane $\mathrm{A}_{2}$. In Goodman and Gilman's The Pharmacological Basis of Therapeutics, 6th edn, pp. 668-681. Eds A. G. Gilman, L. S. Goodman \& A. Gilman. Macmillan, New York.

Morishige, W.K., Pepe, G.J. \& Rothchild, I. (1973) Serum luteinizing hormone, prolactin and progesterone levels during pregnancy in the rat. Endocrinology 92, 1527-1530.

Pepe, G.J. \& Rothchild, I. (1973) Serum progesterone levels in ovariectomized rats injected with progesterone and estrone: regulation to pregnancy maintenance and growth of decidual tissue. Endocrinology 93 , 1193-1199.
Rothchild, I. (1983) Role of progesterone in initiating and maintaining pregnancy. In Progesterone and Progestins, pp. 219-229. Eds C. W. Bardin, E. Milgrom \& P. Mauvais. Raven Press, New York.

Tamada, H. \& Ichikawa, S. (1980) The effect of estrogen on fetal survival in progesterone treated ovariectomized rats. Endocrinol. Japon. 27, 163-167.

Wilson, L. \& Lindsey, R. (1987) Effect of progesterone withdrawal on uterine prostaglandin levels in ovariectomized pregnant rat. Prostaglandins Leukotrienes Med. 29, 95-105.

Received 18 October 1989 